University of Nebraska - Lincoln

DigitalCommons@University of Nebraska - Lincoln

1988

\title{
Response of Natural and Factitious Hosts to the Ectoparasite Euplectrus plathypenae (Hymenoptera: Eulophidae)
}

\author{
T. A. Coudron \\ Biological Control of Insects Research Laboratory, USDA-ARS, Columbia, Missouri, \\ tom.coudron@ars.usda.gov \\ B. Puttler \\ Biological Control of Insects Research Laboratory, USDA-ARS, Columbia, Missouri
}

Follow this and additional works at: https://digitalcommons.unl.edu/entomologyother

Part of the Entomology Commons

Coudron, T. A. and Puttler, B., "Response of Natural and Factitious Hosts to the Ectoparasite Euplectrus plathypenae (Hymenoptera: Eulophidae)" (1988). Entomology Papers from Other Sources. 103.

https://digitalcommons.unl.edu/entomologyother/103

This Article is brought to you for free and open access by the Entomology Collections, Miscellaneous at DigitalCommons@University of Nebraska - Lincoln. It has been accepted for inclusion in Entomology Papers from Other Sources by an authorized administrator of DigitalCommons@University of Nebraska - Lincoln. 


\title{
Response of Natural and Factitious Hosts to the Ectoparasite Euplectrus plathypenae (Hymenoptera: Eulophidae)
}

\author{
T. A. COUDRON AND B. PUTTLER
}

\author{
Biological Control of Insects Research Laboratory, USDA-ARS, \\ Columbia, Missouri 65205
}

\begin{abstract}
Ann. Entomol. Soc. Am. 81(6): 931-937 (1988)
ABSTRACT We tested natural and factitious host insects for their physiological responses to stinging by the gregarious ectoparasite, Euplectrus plathypenae Howard, and observed hosts injected with tissue from the lower reproductive tract of the female parasitoid. Tests included eight recorded lepidopteran hosts and larvae of 36 other species of Lepidoptera not previously recorded as hosts, plus 19 species in six other orders. The arrestment of development produced by $E$. plathypenae was expressed in all natural hosts and in most, but not all, insects outside the natural host range of the parasite.
\end{abstract}

KEY WORDS Insecta, arrestment, molt inhibition, parasitism

Euplectrus spp. are naturally gregarious ectoparasites that develop on noctuid and geometrid larvae (Noble 1938, Neser 1973, Gerling \& Limon 1976 , Puttler et al. 1980). They inhibit host molting once stinging (=puncture with the ovipositor), oviposition (=egg deposition), or parasitism (=stinging and oviposition) has occurred. Oviposition ranges from 1 to $>10$ eggs per host. Molting inhibition usually occurs without host paralysis and prevents shedding of the cuticle, which is the site of attachment of the parasite's eggs. In contrast, almost all other hymenopteran ectoparasites (e.g., Braconidae, Ichneumonidae, Eulophidae, and Bethylidae) of lepidopteran and coleopteran larvae paralyze their hosts (Beard 1952, Puttler 1963, Gordh 1976). Paralysis occurs when the female injects venom into the host before or at the time of oviposition.

Euplectrus puttleri (Gordh) and E. kuwanae (Crawford) are host specific (Puttler et al. 1980, Uematsu 1980). In contrast, E. plathypenae Howard has several lepidopteran host species (Wall \& Berberet 1974, Krombein et al. 1979). All three species arrest the development of the host. Oviposition and parasitism of Trichoplusia ni (Hübner) by E. plathypenae affect the molting hormone titer, arrest molting, and prevent new cuticle formation of the host (Coudron \& Kelly 1985).

Our study examines the effect of E. plathypenae and an extract of the lower reproductive tract from E. plathypenae on some of its recorded hosts as well as on other insect hosts. The species was chosen because it is polyphagous and parasitism of more species might be possible.

\section{Material and Methods}

Parasite Rearing. Euplectrus plathypenae were reared on third- and fourth-instar fall armyworm Spodoptera frugiperda (J. E. Smith), and maintained on a semisynthetic modified wheat germ diet (Wilkinson et al. 1972). Ovipositional chambers for the parasite consisted of 0.35-liter paper cartons that contained host diet, honey drops on a plastic Petri dish lid, and two host larvae per female parasite. The larvae were exposed to parasitism for $24 \mathrm{~h}$, removed from the ovipositional chamber, and maintained on diet as the parasites developed. Emerging parasites were kept in an acrylic cage ( 30 by 30 by $30 \mathrm{~cm}$ ), two males per three females, and were supplied with water and honey. Four days were allotted for mating before the adults were used in parasitism tests.

Host Insect Rearing. All tested insect species were obtained from laboratory cultures maintained at the Biological Control of Insects Research Laboratory insectary, provided by cooperating entomologists, or were field collected in Missouri. Fieldcollected insects that could not be maintained on an artificial diet were reared on the host plant from which they had been collected. Laboratory-reared insects were maintained individually on wheat germ diets in $10-\mathrm{ml}$ containers or as groups in $50-\mathrm{ml}$ containers. Developing host insects were observed through each stadium and the times of ecdysis were recorded. Penultimate instars were used for these studies. Rearing and testing of insects were done at $23-26^{\circ} \mathrm{C}, 40-60 \% \mathrm{RH}$, and 12:12 (L:D) photoperiod.

Parasitism Procedure. Euplectrus plathypenae was tested by using 23 noctuid species (including seven species previously recorded as natural hosts), larvae of 18 other lepidopterans representing 10 families and including one species previously recorded as a natural host, and seven species from four nonlepidopteran insect orders. Immature host insects were parasitized in the second quarter of their penultimate stadium to avoid physical disturbance of growth and development. For parasitism, female Euplectrus were transferred into $50-\mathrm{ml}$ host-rearing chambers $(5-10$ parasites/im- 
Table 1. Larvae and nymphs of insects parasitized in the laboratory to determine the effect of E. plathypenae on development and molting

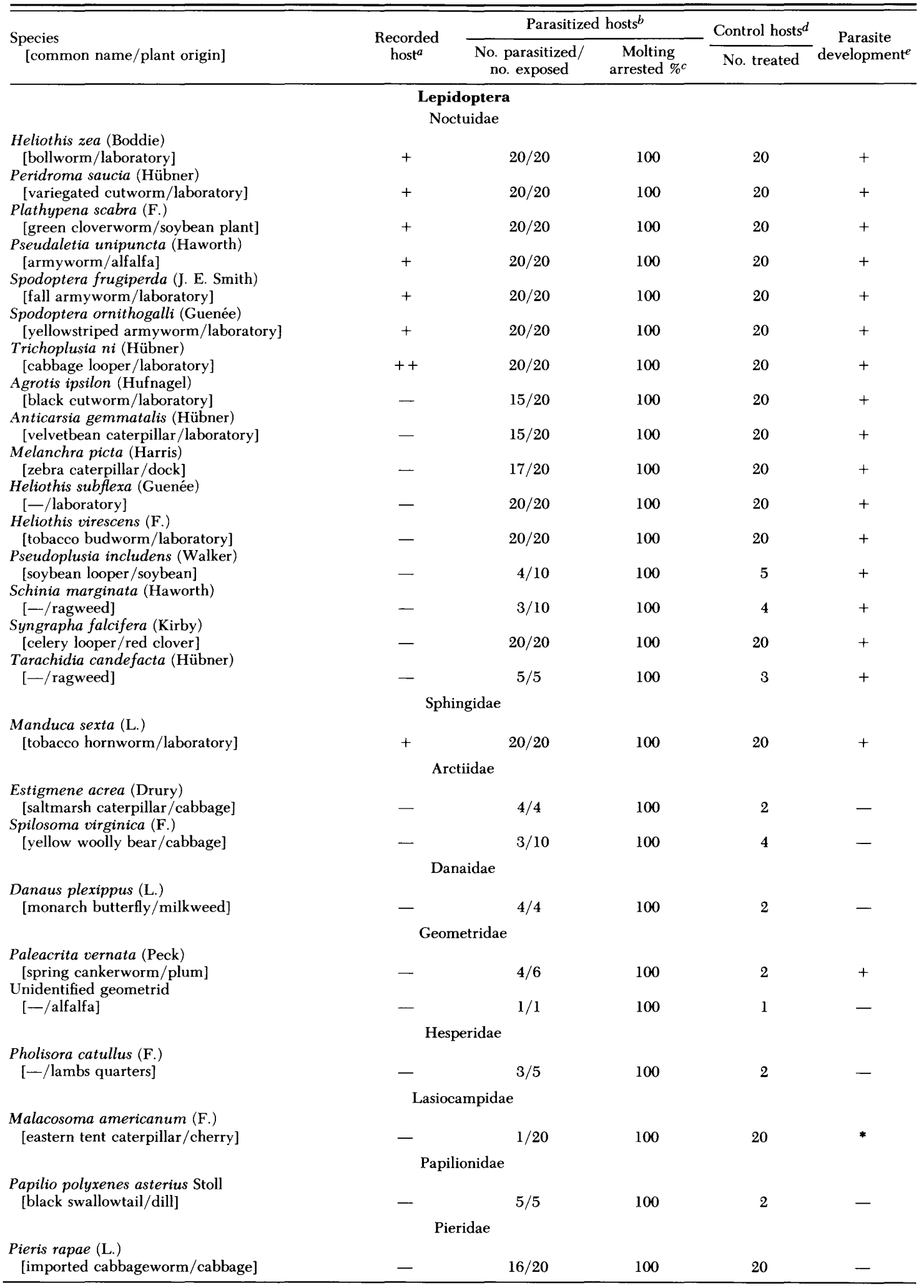


November 1988 Coudron \& Puttler: Host Responses to Ectoparasite

Table 1. Continued.

\begin{tabular}{|c|c|c|c|c|c|}
\hline \multirow{2}{*}{$\begin{array}{l}\text { Species } \\
\text { [common name/plant origin] }\end{array}$} & \multirow{2}{*}{$\begin{array}{l}\text { Recorded } \\
\text { host }^{a}\end{array}$} & \multicolumn{2}{|c|}{ Parasitized hosts ${ }^{b}$} & \multirow{2}{*}{$\frac{\text { Control hosts }^{d}}{\text { No. treated }}$} & \multirow{2}{*}{$\begin{array}{c}\text { Parasite } \\
\text { developmente }\end{array}$} \\
\hline & & $\begin{array}{l}\text { No. parasitized/ } \\
\text { no. exposed }\end{array}$ & $\begin{array}{l}\text { Molting } \\
\text { arrested \%c }\end{array}$ & & \\
\hline $\begin{array}{l}\text { Colias eurytheme (Boisduval) } \\
\text { [alfalfa caterpillar/alfalfa] }\end{array}$ & - & $8 / 10$ & 100 & 5 & - \\
\hline \multicolumn{6}{|c|}{ Pyralidae } \\
\hline $\begin{array}{l}\text { Diatraea grandiosella (Dyar) } \\
\text { [southwestern corn borer/laboratory] }\end{array}$ & - & $10 / 15$ & 100 & 5 & - \\
\hline $\begin{array}{l}\text { Evergestis rimosalis (Guenée) } \\
\text { [cross-striped cabbageworm/cabbage] } \\
\text { Homoeosoma electellum (Hulst) }\end{array}$ & - & $2 / 2$ & 100 & 2 & - \\
\hline $\begin{array}{l}\text { [sunflower moth/laboratory] } \\
\text { Ostrinia nubilalis (Hübner) }\end{array}$ & - & $2 / 5$ & 100 & 3 & - \\
\hline $\begin{array}{l}\text { [European corn borer/laboratory] } \\
\text { Loxostege commixtalis (L.) }\end{array}$ & - & $10 / 10$ & 100 & 5 & - \\
\hline $\begin{array}{l}\text { [alfalfa webworm/alfalfa] } \\
\text { Hellula rogatalis (Hulst) }\end{array}$ & - & $4 / 5$ & 100 & 5 & - \\
\hline [cabbage webworm/cabbage] & - & $3 / 5$ & 100 & 2 & - \\
\hline \multicolumn{6}{|c|}{ Yponomeutidae } \\
\hline $\begin{array}{l}\text { Plutella xylostella }(\mathrm{L} .) \\
\text { [diamondback moth/laboratory] }\end{array}$ & - & $10 / 20$ & 100 & 5 & - \\
\hline \multicolumn{6}{|c|}{$\begin{array}{l}\text { Coleoptera } \\
\text { Chrysomelidae }\end{array}$} \\
\hline $\begin{array}{l}\text { Crioceris asparagi }(\mathrm{L} .) \\
\quad \text { [asparagus beetle/asparagus] }\end{array}$ & - & $9 / 15$ & 0 & 10 & - \\
\hline \multicolumn{6}{|c|}{ Curculionidae } \\
\hline $\begin{array}{l}\text { Hypera postica (Gyllenhal) } \\
\text { [alfalfa weevil/alfalfa] }\end{array}$ & - & $4 / 10$ & 0 & 5 & - \\
\hline \multicolumn{6}{|c|}{$\begin{array}{l}\text { Diptera } \\
\text { Muscidae }\end{array}$} \\
\hline $\begin{array}{l}\text { Musca domestica (L.) } \\
\text { [house fly/laboratory] }\end{array}$ & - & $15 / 20$ & 0 & 20 & - \\
\hline \multicolumn{6}{|c|}{ Sarcophagidae } \\
\hline $\begin{array}{l}\text { Ravinia lherminieri (Robineau-Desuoidy) } \\
{[- \text { /bovine dung }]}\end{array}$ & - & $10 / 20$ & 0 & 5 & - \\
\hline \multicolumn{6}{|c|}{ Syrphidae } \\
\hline $\begin{array}{l}\text { Syrphus sp. } \\
{[-/ \text { milkweed }]}\end{array}$ & - & $2 / 10$ & 0 & 5 & - \\
\hline \multicolumn{6}{|c|}{ Neuroptera } \\
\hline $\begin{array}{l}\text { Chrysopa carnea (Stephens) } \\
\text { [common green lacewing/laboratory] }\end{array}$ & - & $4 / 10$ & 100 & 10 & - \\
\hline
\end{tabular}

$a+$, previously recorded (see Krombein et al. 1979); ++ , previously recorded in our records and referenced by Wall \& Berberet (1974); - , not recorded before in the literature.

${ }^{b}$ Studies done with insects parasitized under controlled laboratory conditions.

$c$ Percentage of parasitized hosts that had arrestment in development at the point of molting.

${ }^{d}$ Insects were held under the same conditions as the treated insects, except there was no exposure to the parasite. All of the control species developed normally.

$e+$, successful development of the parasite through to the adult stage; - , incomplete development of the parasite; ${ }^{*}$, the host died as a result of parasitism and before the development of the parasite could be determined.

mature host) and removed 6-12 h later. Control hosts were treated identically to parasitized hosts but were not exposed to parasites. Control and parasitized hosts were observed for molting every $8 \mathrm{~h}$.

Injection Procedure. Insects that could be handled and injected during the penultimate instar were selected from available species and subjected to injection tests. An extract of tissue dissected from the lower reproductive tract of E. plathypenae females was injected into eight lepidopteran and 15 nonlepidopteran insect species. The tissue was ho- mogenized in $40 \mathrm{mM} \mathrm{KCl}$ (potassium chloride) and centrifuged at $4,500 \times g$ for $10 \mathrm{~min}$. A 5 - $\mu$ l aliquot of the supernatant was injected into the abdominal hemocoel of each test insect by using a 10- $\mu$ l syringe with a 33-gauge needle. Dilutions of the supernatant were prepared by altering the amount of the $\mathrm{KCl}$ solution. The amount injected was expressed in parasite equivalent units (PEU); one unit represented the amount of material extracted from one female parasite. Response to an injection was correlated with concentration. Two and four PEU 
Table 2. Development and molting of insect larvae and nymphs tested with injection of an extract from E. plathypenae

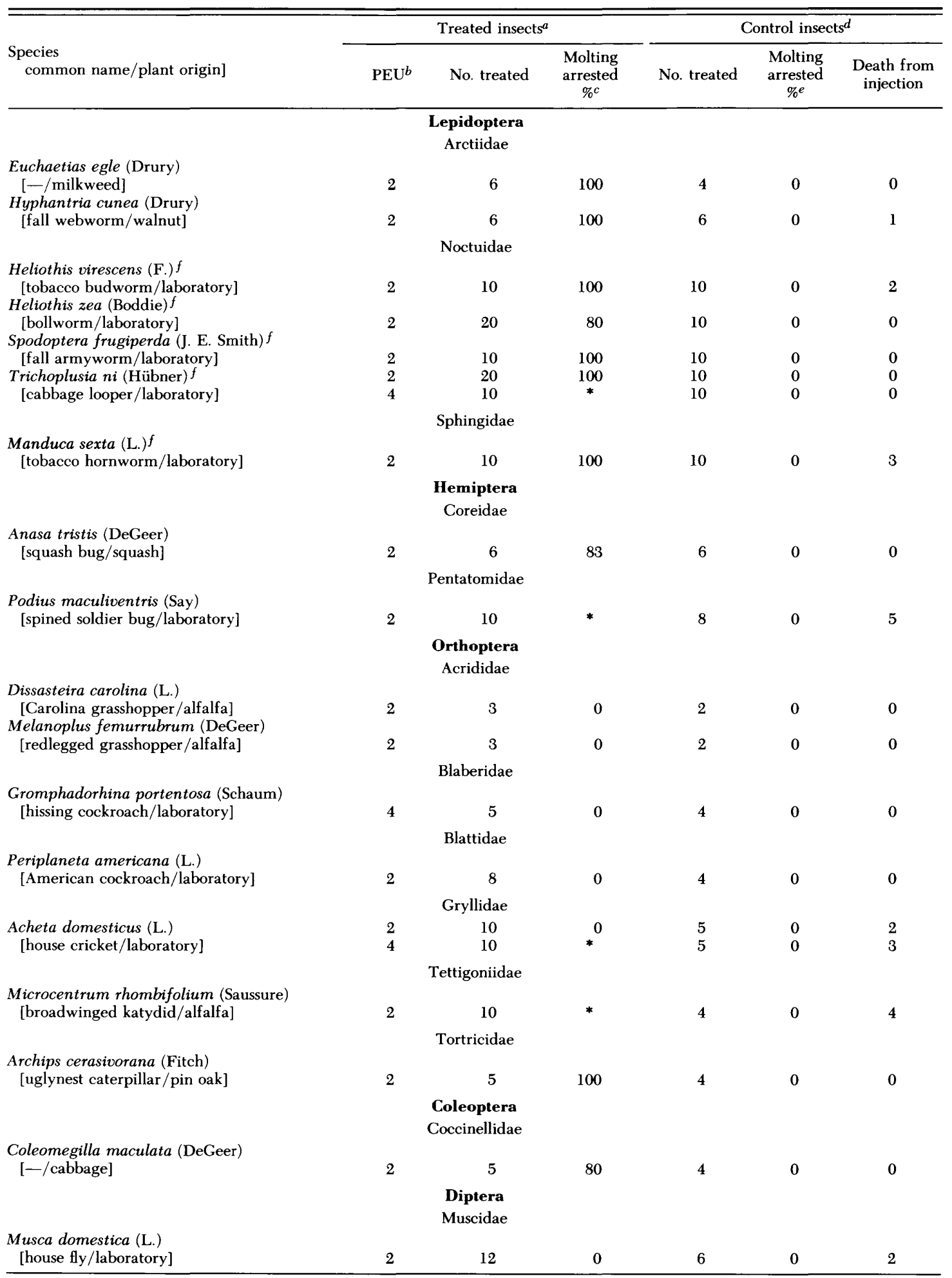

${ }^{a}$ Insects were mechanically injected in the abdominal hemocoel with $5 \mu \mathrm{l}$ of an extract from E. plathypenae.

$b$ The lower reproductive tract of the female E. plathypenae was excised, homogenized, centrifuged, and the supernatant used for injections. One PEU represents the supernatant from the homogenization of one lower reproductive tract.

${ }^{c}$ Percentage of injected hosts which exhibited arrestment in development at the point of molting; ${ }^{*}$, the host died as a result of the injection of the active substance and before the development of the host could be measured. 
were used based on preliminary data showing $T$. $n i$ development to be arrested at $0.1 \mathrm{PEU}$ and death to occur at 4.0 PEU (T.A.C., unpublished data). Control insects were injected with $5 \mu$ l of a $\mathrm{KCl}$ solution alone. Control and treated insects were observed for molting every $8 \mathrm{~h}$.

Interpretation of the Data. Arrested development or absence of molting of treated insects was determined by comparing the time of molting with that of control insects held under identical conditions. Parasitized or injected hosts that molted at the same time as their controls were scored "no arrestment of development"; those that molted within $5 \mathrm{~d}$ (endopterygotes) or $10 \mathrm{~d}$ (exopterygotes) after control molting were scored "delayed development"; and those that lived and fed but had not molted for $7 \mathrm{~d}$ (endopterygotes) or $14 \mathrm{~d}$ (exopterygotes) after control molting were scored "developmentally arrested." Under the rearing conditions in these studies, the penultimate stadium of control insects was 2-3 d for the endopterygotes and 5-6 $\mathrm{d}$ for the exopterygotes tested. Death of a host insect following treatment was recorded separately from normal, delayed, or arrested development.

The development of $E$. plathypenae on each test host was observed and recorded as successful if the parasite developed to the adult stage. All other instances were recorded as unsuccessful.

The number of insects treated (parasitized or injected) was low for some test species. This reflects a limited number of larvae available or a low rate of parasitism by E. plathypenae. Where possible, sufficient control larvae of each species were retained to estimate the time of molting.

Voucher specimens of $E$. plathypenae have been deposited in the W. R. Enns Entomological Museum at the University of Missouri, Columbia.

\section{Results}

Effect of Parasitism by $\boldsymbol{E}$. plathypenae. Molting was arrested in 16 noctuid species following parasitism by $\boldsymbol{E}$. plathypenae (Table 1). The parasite developed successfully on all these hosts. Larvae of the remaining seven noctuid species tested (forage looper, Caenurgina erechtea (Cramer); dingy cutworm, Feltia jaculifera (Guenée); bristly cutworm, Lacinipolia renigera (Stephens); green fruitworm, Lithophane antennata (Walker); bronzed cutworm, Nephelodes minians (Guenée); Parastichtis bicolorago (Guenée); spotted cutworm, Xestia c-nigrum (L.)) died following parasitism and before molting.

Molting was arrested in all other lepidopteran larvae parasitized and none died before control molting occurred (Table 1). Successful parasite development occurred only on Manduca sexta (L.)
(Sphingidae), which has been recorded as a natural host, and on Paleacrita vernata (Peck) (Geometridae). The one lasiocampid host tested, Malacosoma americanum (F.), remained alive after the controls molted but died before the parasites had completely developed.

Seven nonlepidopteran insect species were also tested (Table 1). In one (common green lacewing, Chrysopa carnea (Stephens)), molting was arrested; another died after parasitism (European pine sawfly, Neodiprion sertifer (Geoffroy), not listed in Table 1); and the remainder continued to develop after parasitism (Table 1). E. plathypenae did not develop on any of these species.

Injection Test. Arrested development occurred in all lepidopteran species injected with 2 PEU (Table 2). Twenty percent of treated Heliothis zea (Boddie) larvae continued to develop and molt. These larvae bled at the injection puncture and perhaps the injected material was lost. Survival of sham-treated controls was $>70 \%$, indicating a high degree of tolerance by these lepidopteran larvae for injection (Table 2).

Arrested development occurred in only two nonlepidopteran species that survived injection (Table 2). A low percentage of these larvae (20\% and $17 \%$ for Coleomegilla muculata (DeGeer) and Anasa tristis (DeGeer), respectively) continued to develop and molt. These larvae also bled at the injection puncture and the injected material may have been lost. Larvae of six nonlepidopteran species survived injection and continued to develop and molt. Larvae of seven species (asparagus beetle, Crioceris asparagi (L.); Labidomera clivicolis (Kirby); alfalfa weevil, Hypera postica (Gyllendal); Ravinia lherminieri (Robineau-Desvoidy); Syrphus sp.; spined soldier bug, Podius maculiventris (Say); broadwinged katydid, Microcentrum rhombifolium (Saussure)) died following injection (not listed in Table 2).

The nymphal stadium was extended beyond 10 $\mathrm{d}$ for three orthopteroid species tested: Gromphadorhina portentosa (Schaum), Periplaneta americana (L.), and Acheta domesticus (L.); however, all three molted before $14 \mathrm{~d}$ had elapsed. Therefore, the development was delayed but not completely arrested. Because of its large nymphal size, G. portentosa was treated with $4 \mathrm{PEU}$. The house cricket, A. domesticus, which is much smaller, survived treatment at $2 \mathrm{PEU}$, but died when treated with 4 PEU.

\section{Discussion}

Four kinds of host response were observed in these studies: complete arrestment of development at the time of molting, delayed time of molting,

\footnotetext{
${ }^{d}$ Insects were injected with $5 \mu \mathrm{l}$ of a $\mathrm{KCl}$ solution and held at the same conditions as the treated insects.

${ }^{e}$ Percentage of the control insects which exhibited arrestment in development at the point of molting; ${ }^{*}$, the host died as a result of the injection.

$f$ Parasitized by the female E. plathypenae. See Table 1
} 
death, and normal development including molting. Arrested development occurred in endopterygote and exopterygote species.

Molting was arrested in all 44 lepidopteran species subjected to parasitism and injection tests. Eight species parasitized and 4 species injected were recorded as natural hosts. Complete parasite development was observed on 10 other lepidopteran species, indicating that $E$. plathypenae is capable of successful development on some species not recorded as hosts in nature. However, arrested development occurred in 17 species (15 parasitized and 8 injected) without concomitant development of the parasite. Therefore, arrested development in these species is not dependent on the development of the parasite.

The only Heliothis species recorded to be parasitized by $E$. plathypenae is $H$. zea (Krombein et al. 1979). In our study, $H$. virescens (F.) and $H$. subflexa (Guenée) were readily parasitized and supported complete development of the parasite; therefore it is likely that all Heliothis spp. will eventually be recorded as natural hosts of E. plathypenae.

Parasitism of some species is less likely to occur in nature even though their development was arrested. An example of this is the eastern tent caterpillar, M. americanum (F.). The densely setigerous nature of the larva appeared to be an obstacle to parasitism; E. plathypenae had difficulty reaching the larva's cuticle. However, another Euplectrus sp., E. liparidis (Ferrière), has been reared and described from the densely setigerous larvae of the gypsy moth, Lymantria dispar (L.) (Ferrière 1941, Bouček 1977).

This study records the first parasitism of nonlepidopteran species by an eulophid in the tribe Euplectrini. Five nonlepidopteran species (of the seven tested) developed normally following parasitism. This indicates a resistance to the arrestment effect, something not observed with lepidopteran species. The injection technique was used as an additional test of those species that continued to develop following parasitism. Only larvae of the house fly, Musca domestica (L.), survived the injection process. The continued development of this species supports the idea that resistance to the arrestment effect of E. plathypenae is possible in some insect species.

Molting was not arrested, but was measurably delayed, in three orthopteroid species following injection. This may be a dose-response effect where the amount injected was insufficient to arrest the molting process but sufficient to retard the event. A narrow range of tolerance for the injected material was shown by $A$. domesticus, where $2 \mathrm{PEU}$ caused a delay in the molting process and $4 \mathrm{PEU}$ caused death of the immature host.

Identification and characterization of the active substance in E. plathypenae is in progress. This may make possible a new pharmacologically active agent and pest control methodology directed at controlling the molting process in specific insect species.

\section{Acknowledgment}

We recognize and thank D. D. Shackelford and K. Corum for their technical assistance. The cooperation of J. S. Buckner, K. D. Biever, and R. K. Morrison from the USDA-ARS; G. M. Chippendale, R. D. Hall, and A. J. Keaster from the University of Missouri; and P. K. Peters and S. H. Long from our laboratory, who provided host insects from their laboratory colonies, has been greatly appreciated. We also express our appreciation to R. D. Hall for his review of the manuscript.

\section{References Cited}

Beard, R. L. 1952. The toxicology of Habrobracon venom: a study of a natural insecticide. Connecticut Agricultural Experiment Station Bulletin 562.

Bouček, Z. 1977. A faunistic review of Yugoslavian Chalcidoidae (parasitic Hymenoptera). Acta Entomol. Jugosl. Suppl 3.

Coudron, T. A. \& T. J. Kelly. 1985. Euplectrus plathypenae parasitization of Trichoplusia ni. Effect on weight gain, ecdysteroid titer and molting, p. 319. In Symposium, New Concepts and Trends in Pesticide Chemistry ACS Symposium Series No. 276.

Ferrière, C. 1941. New species of Euplectrini (Hym. Chalcidoidea) from Europe, Africa, and Asia. Bull. Entomol. Res. 32: 17-48.

Gerling, D. \& S. Limon. 1976. A biological review of the genus Euplectrus (Hymenoptera-Eulophidae) with special emphasis on E. laphygmae as a parasite of Spodoptera littoralis (Lep. Noctuidae). Entomophaga 21: 179-187.

Gordh, G. 1976. Goniozus gallicola Fouts, a parasite of moth larvae, with notes on other bethylids ( $\mathrm{Hy}$ menoptera: Bethylidae; Lepidoptera: Gelechiidae). USDA Technical Bulletin 1594.

Krombein, K. V., P. D. Hurd, Jr., D. R. Smith \& B. D. Burks. 1979. Catalogue of Hymenoptera in America north of Mexico, vol. 1. Smithsonian Institution Press, Washington, D.C

Neser, S. 1973. Biology and behaviour of Euplectrus species near Laphygmae Ferrière (Hymenoptera: Eulophidae). Entomology Memoir, Department of Agricultural Technical Services, Republic of South Africa 32.

Noble, N. S. 1938. Euplectrus agaristae Craw. A parasite of the grape vine moth (Phalaenoides glycine Lew.). Science Bulletin, Dept. Agric. New South Wales 63: 5-27.

Puttler, B. 1963. Notes on the biology of Hemiteles graculus (Hymenoptera: Ichneumonidae) parasitizing the alfalfa weevil, Hypera postica. Ann. Entomol. Soc. Am. 56: 857-859.

Puttler, B., G. Gordh \& S. H. Long. 1980. Bionomics of Euplectrus puttleri Gordh, new species, an introduced parasite of the velvetbean caterpillar, Anticarsia gemmatalis from South America. Ann. Entomol. Soc. Am. 73: 28-35.

Uematsu, H. 1980. Bionomics of Euplectrus kuwanae Crawford (Hymenoptera: Eulophidae), a parasitoid of Argyrogramma albostriata (Bremer et Grey). Appl. Entomol. Zool. 16: 57-59. 
Wall, R. \& R. C. Berberet. 1974. The life cycle of Euplectrus plathypenae, a gregarious external parasitoid of peanut forage feeders in Oklahoma. Environ. Entomol. 3: 744-746.

Wilkinson, J. D., R. K. Morrison \& P. K. Peters. 1972. Effect of Calco Oil Red N-1700 dye incorporated into a semi-artificial diet of the imported cabbageworm, corn earworm, and cabbage looper. J. Econ. Entomol. 65: 264-268.

Received for publication 13 August 1987; accepted 7 June 1988. 